\title{
S.......
}

\section{シンクロトロン放射光とレーザーの組み合わせによる 光電子分光実験}

\author{
高橋 和敏，東 純平，鎌田 雅夫 \\ 佐賀大学 シンクロトロン光応用研究センター ( ₹840-8502 佐賀市本庄町1)
}

\section{Photoemission Study Using a Combination of Synchrotron Radiation and Laser}

\author{
Kazutoshi TAKAHASHI, Junpei AZUMA, and Masao KAMADA \\ Synchrotron Light Application Center, Saga University, I Honjo-cho, Saga 840-8502
}

(Received May 19, 2006)

\begin{abstract}
Photoemission spectroscopy using a combination of synchrotron radiation (SR) and a laser is fascinating since various laser-induced phenomena occurring on solids and surfaces are directly observable. A pump-probe technique using SR and a Ti:sapphire laser that is synchronized with the SR can provide time-resolved photoemission spectra in the nanosecond region. Using this system, we have studied the surface photo-voltage effects on an $\mathrm{n}-\mathrm{GaAs}(100)$ surface. We have also constructed an experimental system that enables timeresolved photoemission spectroscopy in the microsecond region. Time-resolved photoemission spectra in the microsecond region can be obtained using a laser light from Ti:sapphire regenerative amplifier with a frequency of $10-300 \mathrm{kHz}$ and a gate system with a time window in the range of $10 \mathrm{~ns}$ to $50 \mathrm{~ms}$ for the photoemission signal.
\end{abstract}

Key Words: Photoemission spectroscopy, Synchrotron radiation, Pulsed laser, Time-resolved technique

1.はじめに

シンクロトロン放射光とレーザーは，50年余りの歴史 の中で共に優れた光源として発展し, 今日では基礎科学 研究のみならず応用面においても広く利用されている。 放射光には遠赤外からX線にいたる波長連続性, 高繰り返 しの短パルス性, 安定性, 指向性, 清浄性, 偏光性など の優れた特徵があり，レーザーには単色性，短パルス 性，指向吽，高強度，偏光性などの優れた特徽がある が，両者を組み合わせた研究は，1980年のSaileの報告1)に 端を発し，今日までいくつかの放射光施設において行な われてきている. 光電子分光法は, 試料にその仕事関数 よりも大きなエネルギーを持つ光を照射した際に放出さ れる光電子のエネルギー分布を測定することにより，物 質の占有電子状態についての知見を直接的に得ることが できる実験手法である．放射光を励起光源として用いた 場合には励起エネルギーを自由に選択できることや励起 光の偏光状態による励起選択則を利用できることなどの 理由により, 光電子分光法は放射光の利用とともに発展 してきた. また，固体中での励起電子の平均自由行程が 短いために, 軟X線領域の光を励起光として用いた場合, 光電子分光法は表面敏感な測定手法となる. 放射光と レーザーの組み合わせによる光電子実験の例としては,
レーザー照射により新たな秩序状態が形成される光誘起相 転移物質での相転移における価数などの電子状態の変化 や, 半導体表面に拈ける光誘起起電力を内殼光電子ピーク のエネルギーシフトから調べた例が報告されている。 Longらは米国のNSLSにおいて, $\mathrm{Si}(111)$ 表面での光誘起起 電力について Si 2p内殼準位の光電子測定から $20 \mathrm{~ns}$ の時間 分解能で測定している2).フランスのsuper-ACOでは，自 由電子レーザー(パルス幅60 ps) と放射光(パルス幅500 ps) の組み合わせにより，半導体表面の光誘起起電力について の光電子分光実験が行なわれている3-5). また，ドイッ BESSYにおいては， $\mathrm{SiO}_{2} / \mathrm{Si}(100)$ 表面での光誘起起電力に ついて時間分解能 $60 \mathrm{ps}$ での光電子分光実験が行なわれて いる6,7).このほか, ALS, ESRF, Spring-8などの高輝度放 射光施設においても，組み合わせ実験が計画・進行中であ る、本稿では，これまでに我々が行なってきた半導体表面 におけるレーザー励起現象の実験例および九州シンクロト ロン光研究センター内に建設した専用ビームラインでの放 射光とレーザーの組み合わせによる時間分解光電子実験シ ステムについて紹介する。

\section{2. 半導体表面における光誘起起電力の観測}

半導体表面における光誘起起電力効果は，表面における 
エネルギーバンドの曲がりと密接に関係するものであ る. Fig. 1に半導体表面における光誘起起電力の概念図を 示す。半導体表面においては表面準位などのバンド ギャップ中に固有エネルギーを持つ局在準位の存在のた めにフェルミ準位がピン止めされる。この表面の余剰な 電荷を補償するようにバルクの電荷が移動することによ りエネルギーバンドの曲がりが生ずる。この空間電荷層 の厚さは典型的な場合には $100 \mathrm{~nm}$ 程度である。レーザー 光の照射によりこのバンドベンディング領域に電子・正 孔対が生成されると, $\mathrm{n}$-型半導体の場合は, 正孔は表面方 向へ，電子はバルク方向へと表面のポテンシャルカーブ に沿って移動する。この光励起された電荷の空間的分離 は，表面の空間電荷領域に新たな電場を生じさせること になり，表面領域でのバンドベンディングを部分的に補 償することとなる．充分に強い光を照射した場合には， 表面の余剰電荷を完全に遮蔽するほどのキャリアが励起 されバンドベンディングが完全に解消されるとの仮定に 基づき, 飽和状態での表面光誘起起電力の測定からバン ドベンディング量の絶対值を求めることが行なわれてい る8)。また， $20 \mathrm{~K}$ 程度以下の低温下においては，プローブ 光である放射光の照射のみで飽和状態に近い表面光誘起 起電力が生じることが報告されている9).このような半導 体表面におけるバンドベンディングや光誘起起電力効果 はよく知られた半導体の特性であり1950年台から興味を 持たれている課題である10,11)。また，近年においては光工 レクトロニクスなどへの応用的観点からも, 表面での励 起キャリアのダイナミクスについて研究が進められてい る、ここでは，放射光とレーザーの組み合わせによるポ ンプープローブ光電子実験を用いて GaAs (100) 表面におけ る光誘起起電力をナノ秒の時間領域で調べた結果につい て紹介する。

Fig. 2に実験配置の概略を示す. 実験は分子科学研究所

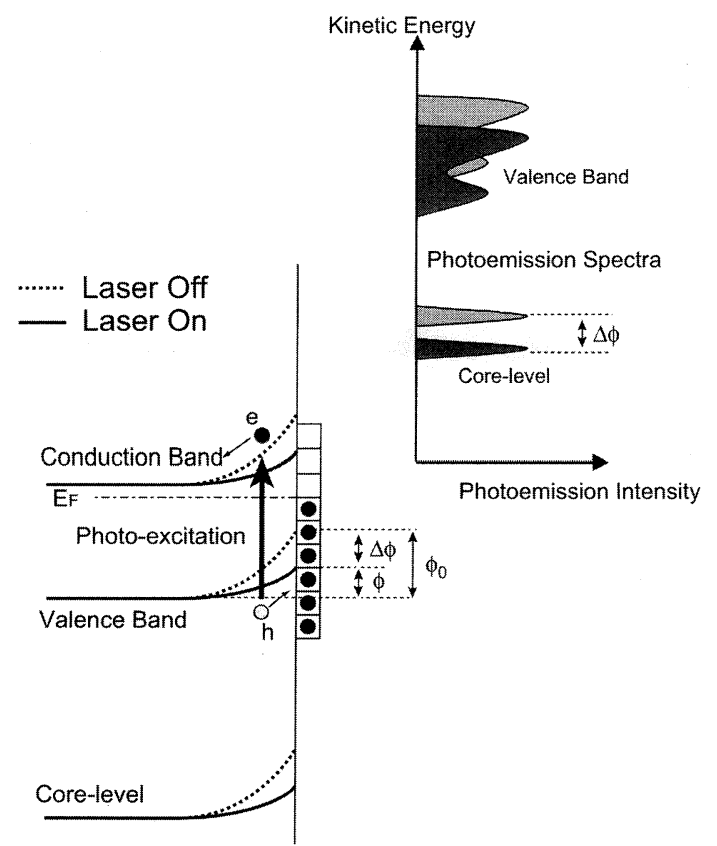

Fig. 1 The schematic diagram of the surface photo-voltage effect on n-type semiconductor surface.

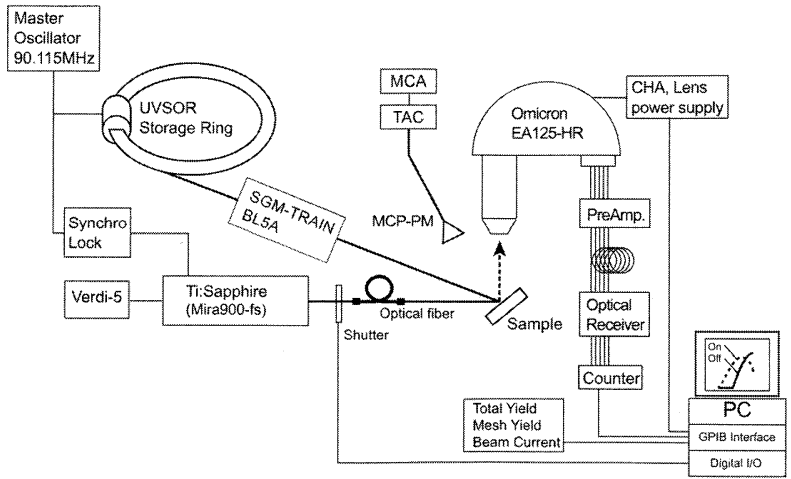

Fig. 2 The schematic diagram of pump-probe photoemission measurement with SR and Laser in nano-second region.

UVSORのビームラインBL5A ${ }^{12,13)}$ において行なった。試料 は, n-型ドープ $\left(\mathrm{Si}, 1 \times 10^{18} \mathrm{~cm}^{-3}\right)$ のaAs $(100)$ 単結晶であ る. 試料表面の清浄化は, 超高真空雲囲気下でのアニー

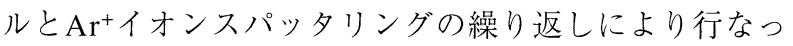
た. 偏向電磁石からの放射光は, SGM-TRAIN型分光器で 分光した後, 試料へ入射される。放射光の繰り返し周波 数はマルチバンチ運転時は $90.115 \mathrm{MHz}$ ，シングルバンチ 運転時は5.63 MHz(マルチバンチ運転時の1/16)である。光 電子分光測定には静電半球型の電子エネルギー分析器を 用いている. 励起光のエネルギー幅も含めた光電子分光 測定のエネルギー分解能は約 $0.2 \mathrm{eV}$ あ゙る.ビームライン に設置されたモードロックTi:Sapphireレーザー装置は，電 子蓄積リングのマスターオシレータからの信号を用いる ことにより放射光と完全同期している。ナノ秒領域での 時間分解光電子測定は，いわゆるポンプ・プローブ法によ り行なった。レーザー光は光ファイバーを用いて測定 チェンバーまで運ばれ，䙼き空の直前に設置したレンズ により放射光が照射される範囲である光電子分光測定の 観測範囲を完全に覆うように試料上へ集光した。また， 測定においては，レーザーの光路上に設置したシャッ ターをスペクトルのデータ点1点でのため込み時間に同期 させて開閉しながら，レーザー照射・非照射下での測定 を交互に行なっており，表面酸化などのスペクトルの経 時変化の影響が打ち消されるようにしている。放射光と レーザーの同期は，両者の試料からの反射光をMCP-PM/ TACシステムを用いて測定することにより確認した。マ ルチバンチ運転時の遅延時間範囲は11ナノ秒までとな る。この時間範囲は，シングルバンチ運転時の放射光 と，放射光の繰り返しと同期したAOモジュレータでレー ザーパルスの一部を切り出すことにより，178ナノ秒まで 拡げることができる。この実験における時間分解能は約 $1.5 ナ ノ$ 秒であり，放射光のパルス幅によって制限されて いるものである。

Fig. 3 (a)にGa $3 d$ 内殼準位のナノ秒領域での時間分解光 電子スペクトルを示す. シングルバンチ運転時の放射光 と，放射光の繰り返しと同期したAOモジュレータでレー ザーパルスの一部を切り出すことにより178ナノ秒までの 時間分解測定を行なっており，励起放射光のエネルギー は100 eV，レーザーの波長は770 nm，レーザーの平均パ 


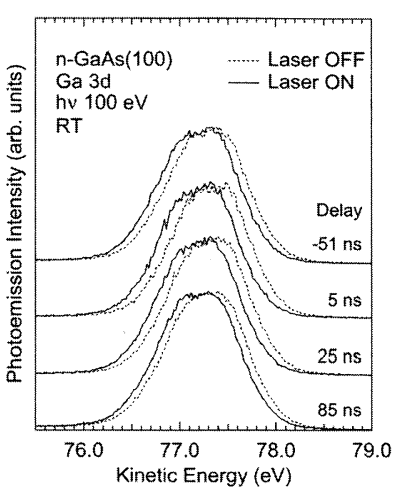

(a)

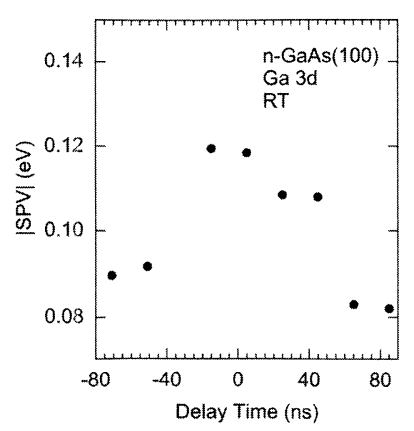

(b)
Fig. 3 (a) Time-resolved Ga $3 d$ photoemission spectra in nano-second region measured by pump-probe technique and (b) time response of the SPV effect in n$\mathrm{GaAs}(100)$ surface.

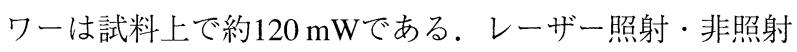
におけるスペクトルをそれぞれ実線と破線で示してい る.また, 図には放射光とレーザーの時間差を併せて示 している. 図に示したように, Ga $3 d$ 準位のピーク位置は レーザー光の照射により低運動エネルギー側へシフトし ている。また, レーザー光の照射によるスペクトル形状 の変化はS/N比および分解能の範囲内で観測されていな い. 一般に, 内殼光電子ピーク位置のシフトの原因とし ては, 着目している表面光誘起起電力によるもののほか に, 表面組成の変化, 試料のチャージアップ, レーザー 照射による熱的な効果, 光励起による価数の变化などの 効果も考えられる. しかしながら, 今回これらの外因的 な効果ついては, スペクトル形状の変化が無いことや, 過去に行なったp-型ドープの試料での結果との比較などか ら無視できるものと考えられる. 光励起により生成され るキャリアの量が元々の熱励起されたキャリアの量に比 ベて多くない場合には, 光誘起起電力効果はバンドベン ディング描像に光励起による余㮃キャリアを組み入れた モデルにより定量的に説明できることを報告してい る14). 図に示したように, Ga 3d準位のピークシフトの大 きさは，放射光とレーザーの時間差が大きくなるととも に減少している。この時間依存性をより詳しく見るため に, Ga 3d準位のピークシフトの大きさを放射光とレー ザーの時間差に対してプロットした結果をFig. 3 (b)に示 す.図に示したように，放射光とレーザーの時間差がゼ 口のとき, 最大 $0.12 \mathrm{eV}$ の光誘起起電力を示している.こ の大きさは時間とともに減少する。また, 放射光とレー ザーの時間差が負の領域においても，約 $0.09 \mathrm{eV}$ のシフト が観測されており，これは先のレーザーパルスにより生 成されたキャリアが完全には緩和していないことに対応 している。これらのことから，n-GaAs (100)表面における 光誘起起電力は室温下において数 $100 \mathrm{~ns}$ 以上残存している ことがわかり，より遅い時間領域についても測定を行な うことが必要である。

\section{3. 九州シンクロトロン光研究センターにおける \\ 放射光とレーザーの組み合わせによる 時間分解光電子実験}

九州シンクロトロン光研究センターは九州地区で初の シンクロトロン放射光源として佐賀県により建設が進め られ，2006年2月にオープンを迎えた。電子蓄積リングの 周長は75.6 mの中規模リングであり, 蓄積エネルギー1.4 $\mathrm{GeV}$, 臨界エネルギー $1.9 \mathrm{keV}$, エミッタンスは $25.5 \mathrm{~nm}-\mathrm{rad}$ である。我々のグループでは，ここに平面型アンジュ レータからの放射光とレーザーとの組み合わせによる高 分解能光電子分光法を中心とした手法により，表面およ び界面におけるダイナミクスを調べることを目的とした 専用ビームラインを建設した。 ここでは，本ビームライ ンにおけるサブマイクロからマイクロ秒領域での時間分 解光電子分光測定のための実験システムについて紹介す る.

ビームラインは九州シンクロトロン光研究センターの BL13に建設された. Fig. 4にビームラインの概略図を示 す. 不等間隔刻線平面回折格子を用いた分光器が前置光 学系と後置光学系の間に設置されている. ビームライン の全長は約 $30 \mathrm{~m}$ であり, 分光器のアーム長は約 $4 \mathrm{~m}$ であ る. 分光器は4枚の球面鏡と3枚の回折格子の組み合わせ により，4種類の偏角 $\left(174 ， 170 ， 167 ， 15^{\circ}\right)$ で使用できる ようにしている。これにより，高次光や迷光を抑えなが ら真空紫外から軟X線領域におよぶ広い範囲をカバーする ことが可能である. 分光器のエネルギー分解能はスリッ ト幅10 mmのときに15-600 eVのエネルギー範囲でE/ $\Delta \mathrm{E}>$ 10000 達成できることが，光源追跡法を用いたシミュ レーションにより見積もられている。 また, 試料位置で のスポットサイズは横方向が 30-100 mm, 縦方向が5-30 $\mathrm{mm}$ ，フォトン数は $1 \times 10^{10} \sim 5 \times 10^{12}$ photons $/ \mathrm{sec} / 300 \mathrm{~mA}$ と 見積もられている15).

ビームラインのエンドステーションには高分解能光電 子分析装置を中心とした測定システムが設置されてい る. Fig. 5にエンドステーションの概略図を示す。エンド ステーションは3つの真空槽から構成されている. 試料分 析槽には電子軌道半径 $200 \mathrm{~mm}$ の高分解能光電子エネル ギー分析器 (MBS-TOYAMA製, A-1), 循環型ヘリウムク ライオスタット, 高輝度型ヘリウムランプおよびッイン アノードX線管が備えられている。試料は循環型へリウム

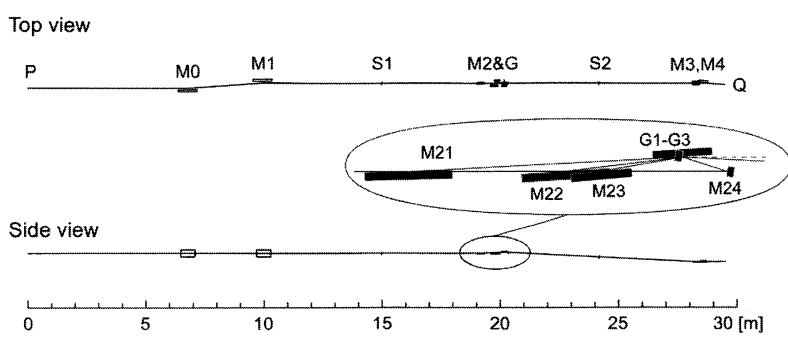

Fig. 4 The schematic layout of the beamline. The monochromator in the beamline is based on VLSPGM consisted of four spherical mirrors and three gratings. 


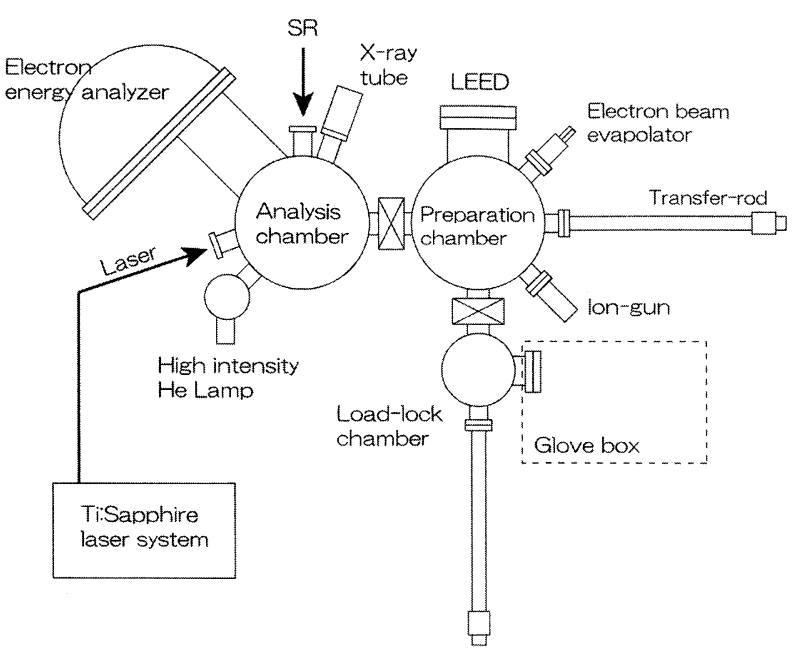

Fig. 5 The schematic layout of the end-station at BL13U.

クライオスタットの先端部に固定され，ヒーターとの併 用により試料温度10-450 Kでの光電子測定が可能である. 光電子分析装置のエネルギー分解能は，パスエネルギー2

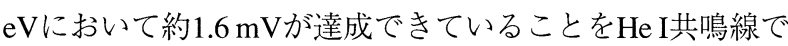
の励起によりキセノンガスの $5 \mathrm{p}$ 内殼準位のピーク幅を測 定した結果から確認している。試料分析槽は超高真空 ゲートバルブを介して試料準備槽と接続されている。試 料準備槽にはイオンスパッ夕銃, 試料加熱・冷却機構, 電子ビーム蒸着源, 水晶振動子膜厚計, 低速電子回折装 置などが備えられており, 試料のクリーニングや金属薄 膜をはじめとする多種の薄膜試料の作製を行なうことが できる，測定する試料は，試料準備槽に取り付けられた ロードロック槽から真空中に導入される。また，ロード ロック室にはグローブボックスが接続できるようになっ ており，溶液中などで調製した試料についても大気にさ らすことなく光電子測定を行なうことが可能である。工 ンドステーションの近くには, シンクロトロン光とレー ザー光との組み合わせによる光電子実験を行なうため に，モードロックのチタン-サファイヤレーザーおよび再 生増幅器からなるレーザーシステムを2基設置している。 これらの実験システムにより，半導体表面における表面 光誘起起電力効果や光誘起相転移現象について, 価電子 帯や内殼準位の光電子測定から調べることができる．特 に, 光電子エネルギー分析器の検出器部にはゲート機能 が備えられており，これを用いてサブマイクロからマイ クロ秒領域での時間分解光電子分光測定を行なう.

Fig. 6にゲート検出器を用いた時間分解光電子測定の実 験配置の概略を示す.アンジュレータからの放射光は不 等間隔刻線平面回折格子分光器 (VLS-PGM)により単色化 され, 試料に入射される.また, レーザーは試料分析槽 の瞀き空の手前まで光ファイバーを用いて輸送しレンズ で集光されて試料に入射される。レーザーのスポットサ イズは放射光のスポットサイズを覆うように調整され る。レーザーの繰り返し周波数10-300 kHzに対して, 放射 光の繰り返し周波数はマルチバンチモードでの運転にお いては500 MHzであるので，放射光はほぼ連続光とみなす ことができる. 光電子エネルギー分析器の検出器はマイ

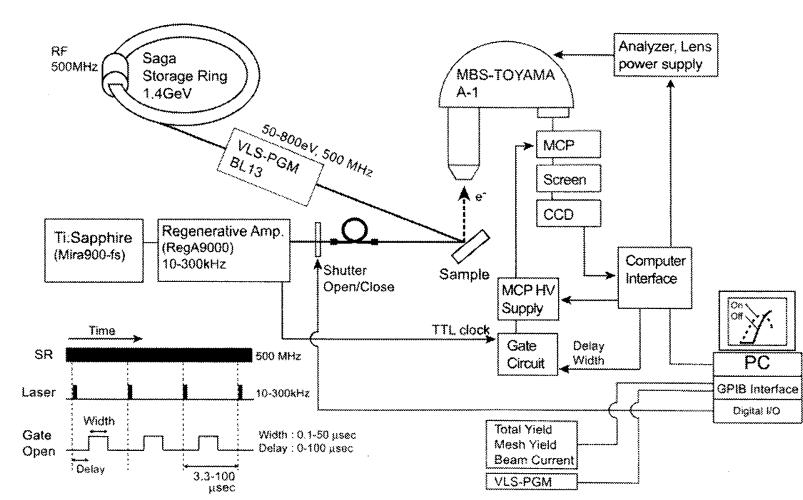

Fig. 6 The schematic diagram of time-resolved photoemission measurement with gated detector in micro-second region.

クロチャンネルプレート (MCP)-蛍光スクリーン-CCDカメ ラによる2次元検出器である。通常, $\mathrm{MCP}$ の初段には光電 子エネルギー分析器のパスエネルギーに対して $80 \%$ の大 きさの阻止電圧が印加されており，ノイズを抑えるため にアナライザー内の電極で発生する散乱電子がMCPに入 射しないようにされている．時間ゲート検出機能は，こ の阻止電圧をレーザー装置からのTTL信号に同期させて変 化させることにより，エネルギー分析器の半球部を通過 した光電子のうち特定の時間領域の光電子のみが検出器 に入射できるようにすることにより実現している。ゲー 卜検出器の時間幅は0.01-50 $\mu \mathrm{s}$, 遅れ時間は0-100 $\mu \mathrm{s}$ の範囲 で可変である。また，測定用PCから制御可能なシャッ ターをレーザーの光路上に設置している。これによっ て，ゲート検出器の時間幅，遅れ時間，レーザー照射の 有無などの測定条件を複数設定しての光電子測定を1つの 測定ルーチンで行なうことができる.

ゲート機能の試験は，気体分子の光電子分光実験にお いて一般的に使用されている電極付のガスセルを用いて $\mathrm{Xe}^{5} p_{3 / 2}$ ピークを測定することにより行なった。 ガスセル 内の電極に，パルス発生器からの繰り返し周波数 $300 \mathrm{kHz}$ の矩形波の電圧を印加し試料位置における電位をパルス 的に変化させる。これにより観測されるXe ${ }^{5} p_{3 / 2}$ ピーク位 置が周期的に変化するので，その立ち上がり付近を時間 分解測定することによりゲート機能の試験を行なうこと ができる. Fig. 7にゲート機能の試験測定の結果を示す.

Fig. 7において，一番下に示したスペクトルはゲート機能 を用いずに通常の光電子測定によって得られた時間積分 測定でのスペクトルである。このスペクトルにおいて 9.371 と9.392 eVの運動エネルギー位置に観測されるピーク は，それぞれ電極がアース電位の時と電極に電圧が印加

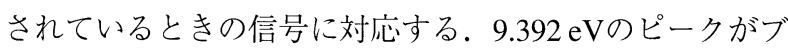
ロードになっているのは，ガスセルの光電子分析装置側 の電極はアース電位に固定されており背面の電極のみに パルス電圧を印加しているために，Xe分子がイオン化さ れる空間に電位勾配があることに起因する。時間分解ス ペクトルは時間幅50 nsに固定し，遅れ時間を50 nsずつ変 化させながら測定した。Fig. 7において，遅れ時間2100 ns からXe ${ }^{5} p_{3 / 2}$ ピークの運動エネルギー位置が変化してい る. $2100 \mathrm{~ns}$ の遅れ時間は試料位置から検出器までの光電 


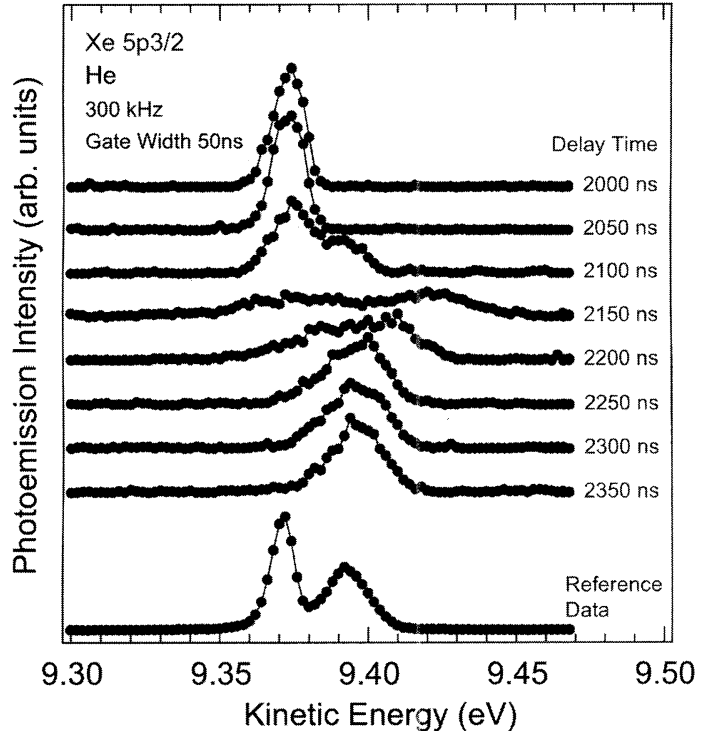

Fig. $7 \mathrm{Xe}^{5} p_{3 / 2}$ photoemission spectra measured using the present gated-detector with the time-window of 50 ns.

子の飛行時間に対応する。また，エネルギーシフトの立 ち上がり付近においてはピーク位置が大きく振れる振る 舞いを示し, $2300 \mathrm{~ns}$ 以降では9.392 eVの運動エネルギー位 置にピークが観測されている。エネルギーシフトの立ち 上がり付近においてピーク位置が大きく振れる振る舞い を示しているのは，電極への印加電圧にはガスセルの静 電容量のためにパルスの立ち上がりにおいて減衰振動す る成分が重なっており，Xe ${ }^{5} p_{3 / 2}$ ピークの運動エネルギー 位置は印加しているパルス電圧と同じように矩形波的に は変化しないためである。このため，今回のゲート機能 の試験ではピーク位置の時間変化の急峻さから時間分解 能を豲密に求めることは困難である。しかしながら, Fig. 7に示したように遅れ時間 $2100 \mathrm{~ns}$ から $2300 \mathrm{~ns}$ までのスぺク トル形状は明確に異なっており，50 nsの時間分解能は達 成できていると考えられる。

以上に示したゲート機能を用いてのサブマイクロから マイクロ秒領域での時間分解光電子分光測定を放射光と レーザーの組み合わせによって行なうことに加えて，よ り早い時間領域に対しては, 放射光と同期させたレー ザーとの組み合わせによるポンプープローブ測定によりナ ノ秒領域の時間分解測定ができるシステムを構築するこ とを進めている。また，レーザーシステム単独で基本波 と3倍高調波のフェムト秒レーザーパルスを用いたポンププローブ測定により, サブピコ秒領域での時間分解測定
ができる環境も整えることができた。今後はこれらの組 み合わせにより，半導体表面でのレーザー励起現象をは じめとする種々のダイナミクス研究を進めていきたいと 考えている.

\section{4. おわりに}

本稿では放射光とレーザーを組み合わせた固体ならび に表面における研究例として, 半導体表面におけるレー ザー励起現象の光電子実験と, 九州シンクロトロン光研 究センター内に建設した専用ビームラインでの放射光と レーザーの組み合わせによる時間分解光電子実験システ ムについて紹介した. 物質の占有電子状態についての知 見を直接的に得ることができる実験手法である光電子分 光測定を，放射光とレーザーのパルス性を用いて時分割 で行なうことは固体および表面におけるレーザー励起現 象の研究に有益なものと考えている. 現在までに, これ らの組み合わせ実験を行なえる環境を九州シンクロトロ ン光研究センター内の専用ビームラインとして整えつつ あり, 今後は, 半導体表面でのレーザー励起現象をはじ めとする種々のダイナミクス研究を進展させたいと考え ている.

\section{参考文献}

1) V. Saile: Appl. Opt. 19 (1980) 4115.

2) J. P. Long, H. R. Sadghi, J. C. Rife, and M. N. Kabler: Phys. Rev. Lett. 64 (1990) 1158

3) M. Marsi, M. E. Couprie, L. Nahon, D. Garzella, T. Hara, R. Bakker, M. Billardon, A. Delboulbe, G. Indlekofer, and A. Taleb-Ibrahimi: Appl. Phys. Lett. 70 (1997) 895.

4) M. Marsi et al.: J. Electron Spectr. Relat. Phenom. 94 (1998) 149.

5) M. Marsi et al.: Phys. Rev. B 61 (2000) R5070.

6) W. Widdra et al.: Surf. Sci. $\mathbf{5 4 3}$ (2003) 87.

7) D. Brocker, T. Gieel, and W. Widdra: Chem. Phys. 299 (2004) 247.

8) L. Kronik and Y. Shapira: Surf. Sci. Rep. 37 (1999) 5.

9) J. E. Demuth, W. J. Thompson, N. J. DiNarde, and R. Imbihl: Phys. Rev. Lett. 56 (1986) 1408.

10) C. G. B. Garrett, and W. H. Brattain: Phys. Rev. 99/2 (1955) 376.

11) E. O. Johnson: Phys. Rev. 111 (1957) 153.

12) M. Kamada, K. Sakai, S-i. Tanaka, S. Ohara, S-i. Kimura, A. Hiraya, M. Hasumoto, K. Nakagawa, K. Ichikawa, K. Soda, K. Fukui, Y. Fujii, and E. Ishiguro: Rev. Sci. Instr. 66 (1995) 1537.

13) M. Kamada, S. Tanaka, K. Takahashi, Y. Doi, K. Fukui, T. Kinoshita, Y. Haruyama, S. Asaka, Y. Fujii, and M. Itoh: Nucl. Instrum. Meth. Phys. Res. A 467/468 (2001) 1441.

14) S. Tanaka, S. D. More, J. Murakami, M. Itoh, Y. Fujii, and M. Kamada: Phys. Rev. B 64 (2001) 155308.

15) K. Takahashi, Y. Kondo, J. Azuma, and M. Kamada: J. Electron Spectr. Relat. Phenom. 144-147 (2005) 1093.
光電子分光法 (photoemission spectroscopy)

物質にその仕事関数よりも大きなエネルギーを持つ単 色光を照射し, 外部光電効果により真空中へ放出される 電子の運動エネルギー分布を測定することにより，物質 の電子状態を調べる実験手法. 真空紫外光により励起さ れた光電子の運動エネルギーは通常10１00 eVである.こ
のエネルギー領域の電子は固体内で非弾性散乱を受けや すく, 非弾性散乱を受けずに放出される光電子は表面近 傍で励起されたものに限られる。このため真空紫外光を 励起光として用いた場合には, 光電子スペクトルは表面 領域の電子状態を反映したものとなる.
(高橋 和敏) 